RAD Conference Proceedings, vol. 4, pp. 142-148, 2020

ISSN 2466-4626 (online) | DOI: 10.21175/RadProc.2020.30

www.rad-proceedings.org

\title{
RADIOLOGICAL ASSESSMENT OF THE BELARUSIAN NUCLEAR POWER PLANT SITE IN THE PRE-OPERATIONAL PERIOD
}

\author{
E.I. Nazarov ${ }^{1,2}{ }^{*}$, A.A. Ekidin', A.V. Vasiljev'1, M.E. Vasyanovich', \\ A.O. Nichiporchuk3, V.A. Kozhemyakin'3, I.A. Kapustin, I.A. Privalov4, \\ E.V. Parkhomchuk5,6, S.A. Rastigeev6, V.V. Parkhomchuk6,7 \\ ${ }^{1}$ Institute of Industrial Ecology UB RAS, Ekaterburg, Russia \\ 2 Ural Federal University, Ekaterinburg, Russia \\ 3 ATOMTEX SPE, Minsk, Republic of Belarus \\ 4 MIREA - Russian Technological University, Moscow, Russia \\ 5 Novosibirsk State University, Novosibirsk, Russia \\ ${ }^{6}$ Institute of Archaeology and Ethnography, Novosibirsk, Russia \\ 7 Budker Institute of Nuclear Physics SB RAS, Novosibirsk, Russia
}

\begin{abstract}
Field studies on the pre-operational period of a Belarusian NPP have allowed us to determine the "background" level of gamma-emitting radionuclides in individual components of the environment. The results of measuring the dose rate at the NPP construction site are from 0.048 to $0.089 \mu \mathrm{Sv} / \mathrm{h}$. External radiation in the surveyed area is at $96 \%$ due to ${ }^{40} \mathrm{~K},{ }^{226} \mathrm{Ra}$ and ${ }^{232} \mathrm{Th}$. The radionuclides in the surface soil layer are: ${ }^{\circ 0} \mathrm{~K}-$ from 530 to

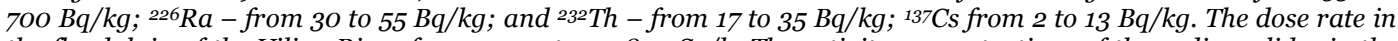
the floodplain of the Viliya River from 0.033 to $0.082 \mu \mathrm{Sv} / \mathrm{h}$. The activity concentrations of the radionuclides in the surface soil layer of the floodplain of the Viliya River are: ${ }^{20} \mathrm{~K}$ - from 390 to $690 \mathrm{~Bq} / \mathrm{kg} ;{ }^{226} \mathrm{Ra}$ - from 33 to $50 \mathrm{~Bq} / \mathrm{kg}$; ${ }^{232} \mathrm{Th}-$ from 15 to $50 \mathrm{~Bq} / \mathrm{kg} ;{ }^{137} \mathrm{Cs}-$ from 3 to $12 \mathrm{~Bq} / \mathrm{kg}$. The activity concentration of carbon-14 and tritium in the dominant vegetation species were determined to be: from 74.4 to $111.5 \mathrm{pMC}$ and less than lower range limit, respectively.
\end{abstract}

Keywords: Belarusian NPP, radiation monitoring, environment, dose rate, radionuclides, activity concentration

\section{INTRODUCTION}

According to the recommendations of the International Atomic Energy Agency (IAEA), radiation monitoring around nuclear power plants (NPPs) at all stages in their life cycle (construction, operation, decommissioning) is necessary [1]. For each stage of the NPP life cycle, there are unique sources of radiation exposure, i.e. relevant sets of radionuclides that determine the main contribution to the exposure of a critical population group.

The selection of the site for the first nuclear power plant in the Republic of Belarus triggered large-scale and comprehensive environment assessments in the Ostrovets district of the Grodno region [2] and in neighboring countries (mainly Lithuania) [3]. The comprehensive environmental monitoring program includes hygienic parameters for assessing radiation doses and the control of ecological contamination. Soil [3], bottom riverbed sediments [3,4], surface water [5] and the atmospheric boundary layer [6] can be selected as objects of environmental studies. The main technogenic radionuclides present in discharges, emissions and radioactive waste during the operation of nuclear power plants, as well as natural radionuclides, have been selected as controlled parameters $[7,8]$. The inclusion of natural radionuclides in the control program is done not only because of the need to consider "background" radiation exposure, but also because there is an opportunity to use the radionuclide ratio method to identify sources of radioactive substances in the environment $[9,10]$.

Systematic observations of the radiation characteristics of the environment, starting from the stage of choosing a construction site, allow us to obtain a relevant assessment of the radiation impact at each stage in the life cycle of a nuclear power plant. Analysis of the source data and research planning can have a significant impact on the volume and quality of the results. As such, it is necessary to consider [1]:

- the estimated characteristics of the sources of emissions, discharges and radioactive waste, including the composition of radionuclides and their physical and chemical form;

- the composition of radionuclides in the environment at the time of the construction of the nuclear power plant;

radionuclide transfer mechanisms in environments, the characteristics that affect transfer and seasonal changes;

*e.nazarov1005@gmail.com 
- possible critical population groups.

As a result of nuclear transformations, hundreds of radionuclides are formed in the reactor core, but only a limited number of them can have an effect on the population and the environment through emissions, discharges and the generation of radioactive waste [1116]. Radioactive substances entering the environment can be in solid, liquid or gaseous states $[17,18]$. The radionuclides which need to detected in order to ensure the safety of the population include a number of difficult-to-detect beta-emitting radionuclides $\left(3 \mathrm{H},{ }^{14} \mathrm{C}\right.$, ${ }^{90} \mathrm{Sr}$ ), the measurement of which requires sophisticated methods for detecting and preparing samples. These cannot be realized in the field [19-22].

The presence of gamma-emitting radionuclides in relation to radiation control allows us to employ field monitoring methods that ensure speed when obtaining data. Field spectrometers, portable dosimeters and radiometers for pedestrian gamma surveys allow for detailed studies to be carried out in local areas. In turn, mobile radiation scanning systems provide significant coverage of the survey areas. The pre-operational studies carried out in the Ostrovets district made it possible to obtain the radioecological characteristics of the environment (activity concentrations of gammaemitting radionuclides, tritium and carbon-14, ambient dose equivalent rate) for use in predicting public exposure to discharges of radioactive substances during normal operation of the NPP.

\section{MATERIALS AND METHODS}

\subsection{Measurement of gamma-emitting radionuclides}

A gamma spectrometric survey of the site around the Belarusian NPP was carried out on a regular grid of $100 \mathrm{~m}$ to $200 \mathrm{~m}$ (Fig. 1).

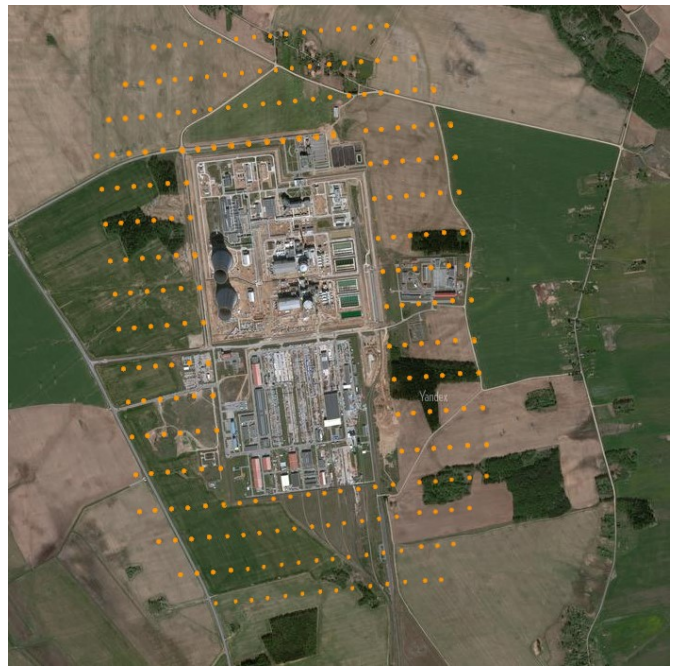

Figure 1. Points in the gamma spectrometric survey.

To take the measurements, a MKS-AT6101DR spectrometer with a scintillation counter was selected. This spectrometer can determine the activity concentrations $(\mathrm{AC})$ of natural radionuclides $\left(4^{\circ} \mathrm{K}\right.$ ${ }^{226} \mathrm{Ra},{ }^{232} \mathrm{Th}$ ), as well as ${ }^{134} \mathrm{Cs}$ and ${ }^{137} \mathrm{Cs}$. In addition, the MKS-AT6101DR spectrometer has functions for measuring the ambient equivalent dose rate and for GPS-binding the measurement points. The data from the spectrometer was verified by duplicating measurements with portable MKS-AT6102A and MKSAT6101C spectrometers with scintillation counters. To study the in-situ content of gamma-emitting radionuclides in water and riverbed sediments, a MKSAT6104DM immersion gamma spectrometer was used. The measurements were supplemented with an automotive gamma survey using a MKS-AT6101C radiation scanning spectrometer with GPS-referenced measurement points, which allowed for the expansion of the studied area.

The data accuracy of the in-situ assessment of radionuclide content was confirmed by sampling soil up to $30 \mathrm{~cm}$ deep and subsequent laboratory studies on the radionuclide content. The location of the sampling points is shown in Fig. 2. Taking into account the maximum value of the dilution factor due to long-term meteorological conditions, a "critical point" was determined - the area where the maximum radiation effect from emissions of radioactive substances from the NPP is realized by all irradiation paths (point 1 in Fig. 2).

To study the riverbank in three regions of the Viliya River, each $1 \mathrm{~km}$ long (Fig. 3), field spectrometry was used. Region 1 is located below the mouth of the Polpe River. Region 2 is located below the water extraction point for the needs of the nuclear power plant, but above the discharge point of the industrial storm drainage (ISD) of the NPP. Region 3 is located below the discharge point of the ISD. In each region, 11 gamma spectrometric measurements of the riverbed were performed. The gamma spectrometric measurement of the water in $4 \pi$ geometry was possible only at four points where the depth of the Viliya River exceeded $1.5 \mathrm{~m}$.

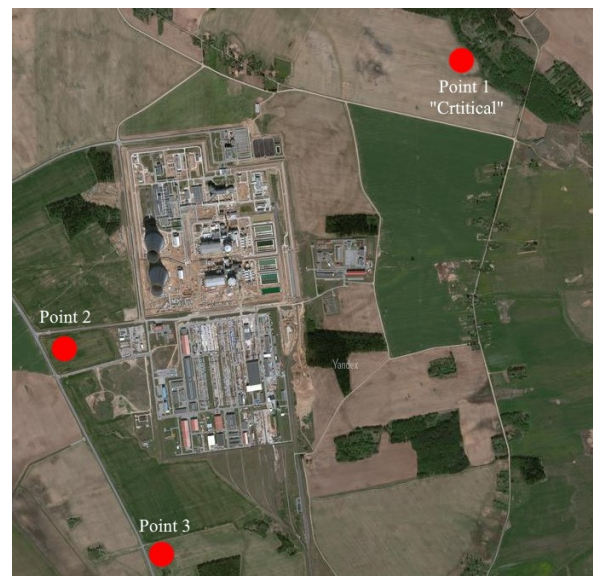

Figure 2. Location of soil sampling points.

In each region of the Viliya River, at least 11 gamma spectrometric measurements of the river bank were taken, along with one water sample and one riverbed sediment sample. Gamma spectrometric studies of the 
riverbank regions were carried out simultaneously with several portable MKS-AT6101DR, MKS-AT6102A and MKS-AT6101S spectrometers.

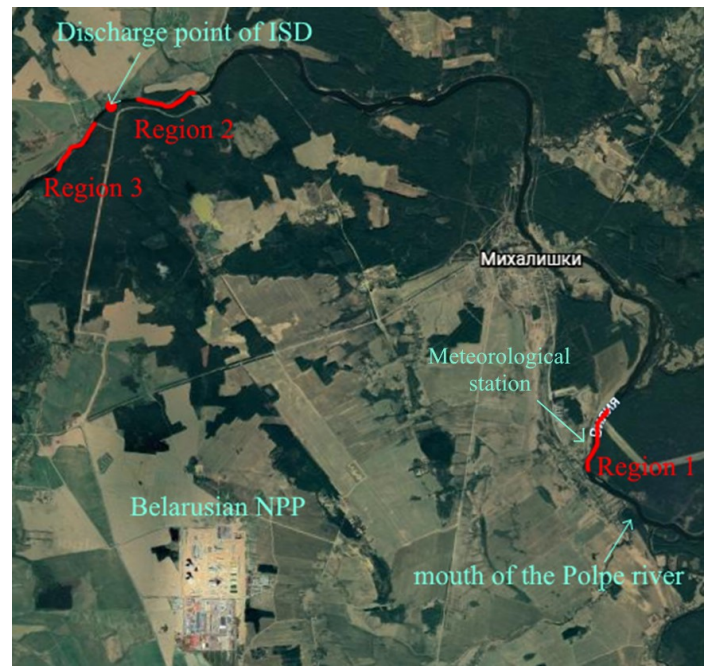

Figure 3. Location of the survey sites on the Viliya River.

\subsection{Carbon-14 and tritium measurments}

To measure the activity concentration of carbon-14 and tritium, the dominant vegetation species were sampled at several sites around the territory of the Belarusian NPP (Table 5).

For determining the activity concentration of tritium, selected vegetation samples were prepared for liquid scintillation counting via a Sample Oxidizer [23]. The samples were burned in an oxygen atmosphere.

The prepared samples were then measured using a Quantulus liquid scintillation counter.

Radiocarbon analysis was carried out with an accelerator mass spectrometer by Novosibirsk AMS Golden Valley staff. 16 samples of green plant mass were sent for radiocarbon analysis. The samples were dried at $50{ }^{\circ} \mathrm{C}$ to a constant weight, crushed, and sent for carbonization and further analysis with an accelerator mass spectrometer (AMS) [24-25].

\section{RESULTS}

The practice of operating nuclear power plants in Russia demonstrates that discharges and emissions have a negligible radiation impact on the population and the environment. Nevertheless, the release of longlived radionuclides into the environment can lead to local anomalous content in various environmental objects [13-14]. Atmospheric emissions form an uneven distribution of radionuclides over the area. As a result of migration processes, radioactive substances are deposited in various soil layers and accumulate in vegetation and living spaces. Discharges lead to the accumulation of radionuclides in riverbed sediments and aquatic and coastal flora and fauna.

The investigated properties of the surface distribution of the activity density of precipitated radionuclides show [26]:
- the continuity of the function characterizing the distribution of activity density over the surface in the area of deposition;

- the independence of the variability of the data sets from the size of the unit of sampling scale;

- quasistationarity - the duration over time of the change in the function of the distribution of activity density over the surface.

The main consequence of the established properties of the surface distribution of the activity density of precipitated radionuclides is that an assessment of the radiation situation in specific areas should not be limited to the assessment of the arithmetic means of measured values. A study of statistical characteristics (determination of the distribution function) obtained data on dose rate, activity concentraton, surface activity density, etc., is required for specific sites. In other words, it is necessary to search for the family of distributions that best describes the samples of the received data. According to the data obtained as a result of the Chernobyl sediment survey, an approximate model of activity density samples for a certain class of sites is a family of lognormal distribution.

In the present work, a field gamma spectrometric method (in situ) was chosen for the survey, which ensures obtaining a sufficient amount of data for a statistically reliable determination of the surface distribution function of gamma emitting radionuclides. The use of sites for in-situ measurements during rapid assessments provides quick information on fresh precipitation. The distribution of the results obtained can be represented as the sum of two lognormal distributions (Fig. 4). This multimodality can be explained by differences in road surfaces (unpaved and asphalt). Equally, the second distribution peak may be due to increased ${ }^{\circ} \mathrm{K}$ content on fertilized lands intended for agricultural use. Table 1 presents the parameters of the obtained distributions, indicating the number of results above the conditional threshold of 0.07 and $0.08 \mu \mathrm{Sv} / \mathrm{h}$.

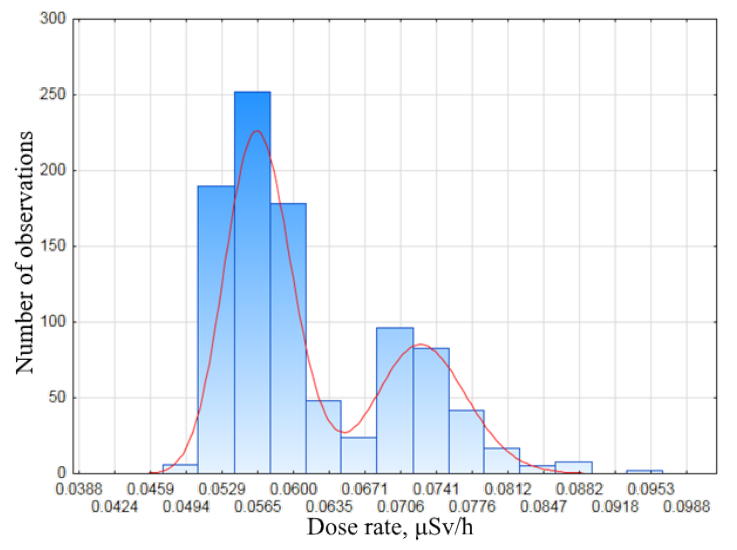

Figure 4. Distribution of the results of the automotive gamma survey. 
E. I. Nazarov et al., Radiological assessment of Belarussian NPP, RAD Conf. Proc., vol. 4, 2020, 142-148

Table 1. Parameters of the distribution of dose rate values according to the results of the automotive gamma survey

\begin{tabular}{|c|c|c|}
\hline & 1 & 2 \\
\hline Arithmetic mean, $\mu \mathrm{Sv} / \mathrm{h}$ & 0.057 & 0.074 \\
\hline Geometric mean, $\mu \mathrm{Sv} / \mathrm{h}$ & 0.057 & 0.074 \\
\hline Sigma LN & 0.06 & 0.06 \\
\hline Percentage higher $0.07 \mu \mathrm{Sv} / \mathrm{h}$ & $0.02 \%$ & $80.6 \%$ \\
\hline Percent. higher $0.08 \mu \mathrm{Sv} / \mathrm{h}$ & - & $8.06 \%$ \\
\hline Number of observations & 691 & 260 \\
\hline
\end{tabular}

The results of pedestrian gamma surveys around the perimeter of the Belarusian NPP site are presented in Fig. 5 and Table 2. Fig. 6 and Table 3 demonstrate the results of a gamma survey on the bank of the Viliya River in a $1 \mathrm{~km}$ zone below the water intake point, discharge point and monitoring section below the confluence of the Polpe River.

Table 2. Parameters for the distribution of dose rate values according to the results of the pedestrian gamma survey.

\begin{tabular}{|c|c|c|c|c|}
\hline $\begin{array}{c}\text { Arithm. } \\
\text { mean, } \\
\mu \mathrm{Sv} / \mathrm{h}\end{array}$ & $\begin{array}{c}\text { Geom. } \\
\text { mean, } \\
\mu \mathrm{Sv} / \mathrm{h}\end{array}$ & $\begin{array}{c}\text { sigma } \\
\mathrm{LN}\end{array}$ & $\begin{array}{c}\text { Percent. } \\
\text { higher } \\
0.07 \\
\mu \mathrm{Sv} / \mathrm{h}\end{array}$ & $\begin{array}{c}\text { Percent. } \\
\text { higher } \\
0.08 \\
\mu \mathrm{Sv} / \mathrm{h}\end{array}$ \\
\hline 0.066 & 0.066 & 0.12 & $30.92 \%$ & $5.36 \%$ \\
\hline
\end{tabular}

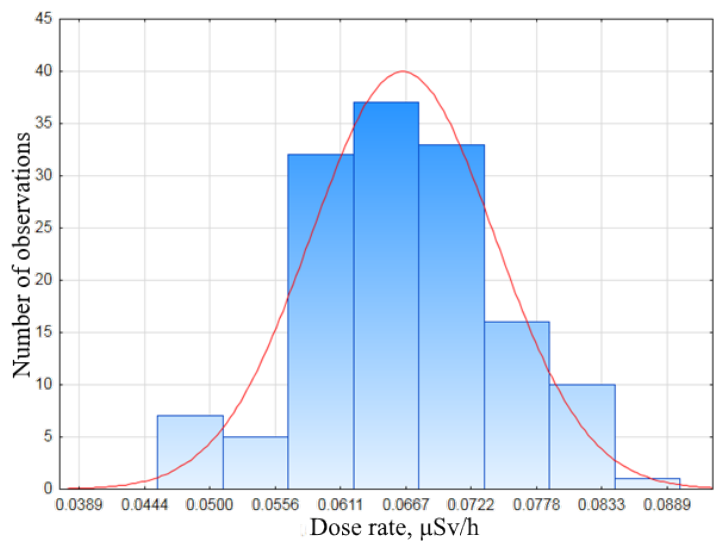

Figure 5. Distribution of the results of the pedestrian gamma survey.

Table 3. Parameters for the distribution of dose rate values according to the results of gamma surveys of the bank of the Viliya River.

\begin{tabular}{|c|c|c|c|c|}
\hline $\begin{array}{c}\text { Arithm. } \\
\text { mean, } \\
\mu \mathrm{Sv} / \mathrm{h}\end{array}$ & $\begin{array}{c}\text { Geom. } \\
\text { mean, } \\
\mu \mathrm{Sv} / \mathrm{h}\end{array}$ & $\begin{array}{c}\text { sigma } \\
\mathrm{LN}\end{array}$ & $\begin{array}{c}\text { Percent. } \\
\text { higher } \\
\text { o.07 } \\
\mu \mathrm{Sv} / \mathrm{h}\end{array}$ & $\begin{array}{c}\text { Number } \\
\text { of } \\
\text { observati } \\
\text { ons }\end{array}$ \\
\hline 0.043 & 0.042 & 0.15 & $0.04 \%$ & 62 \\
\hline
\end{tabular}

As a result of the pedestrian gamma spectrometric survey around the perimeter of the site of the Belarusian NPP (including the control site) and the bank of the River Vilya, the average value of the dose rate was determined at a level of $67 \pm 8 \mathrm{nSv} / \mathrm{h}$.

The results of dose rate measurements using the MKS-AT6101DR and MKS-AT6102 spectrometers were obtained by placing them on the surface of the earth, that is, on the interface between two media: air and soil. A correlation between the dose rate and the activity concentration of individual radionuclides is preserved in different areas of the gamma spectrometric survey, which indicates a homogeneous radio-geochemical spectrum (and indirectly indicates the homogeneous lithogenic composition of the upper geological section) (Fig. 7).

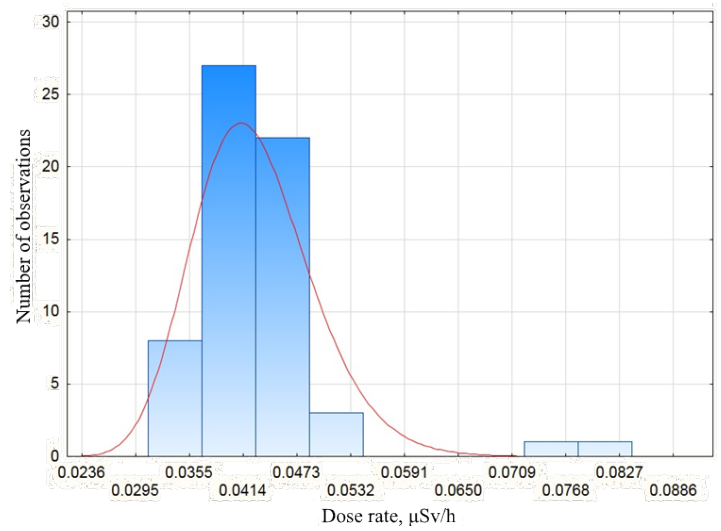

Figure 6. Distribution of the obtained gamma results from the bank of the Viliya River.

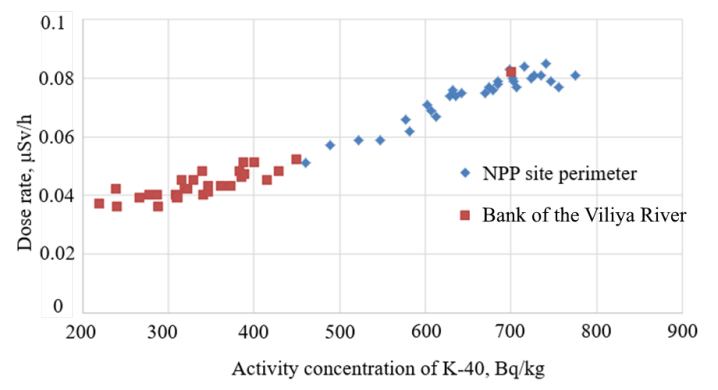

Figure 7. Correlation between dose rate and the activity concentration of $4^{\circ} \mathrm{K}$ at different sites in the gamma spectrometric survey

The results of measuring the activity concentration of radionuclides in soil samples and riverbed sediments are presented in Table 4.

The obtained values of the activity concentration for ${ }^{137 \mathrm{Cs}}$ in the selected soil samples around the Belarusian NPP are less than lower range limit of the field spectrometers used in the work $(50 \mathrm{~Bq} / \mathrm{kg})$. The reliability of the data obtained can be based on a comparison between in-situ results and laboratory measurements of ${ }^{40} \mathrm{~K},{ }^{226} \mathrm{Ra}$ and ${ }^{232} \mathrm{Th}$ activity. The measurements were carried out using a scintillation gamma spectrometer in $4 \pi$ geometry. The data in the tables on the content of natural radionuclides completely coincide with the results of the in-situ measurements. Thus, the results of all the in-situ measurements demonstrated that ${ }^{137 \mathrm{Cs}}$ content is below $50 \mathrm{~Bq} / \mathrm{kg}$ : this was also confirmed by the results of laboratory studies on the soil samples taken from the gamma spectrometric survey.

All the results of the field measurements of the dose rate and activity concentrations of radionuclides do not 
E. I. Nazarov et al., Radiological assessment of Belarussian NPP, RAD Conf. Proc., vol. 4, 2020, 142-148

contradict observational data obtained during special studies on the construction site of the Belarusian nuclear power plant [27].

Table 4. Results of measuring the activity concentrations of ${ }^{40} \mathrm{~K},{ }^{137} \mathrm{Cs},{ }^{226} \mathrm{Ra}$, ${ }^{232} \mathrm{Th}$ in soil samples and bottom sediments.

\begin{tabular}{|c|c|c|c|c|}
\hline \multirow{2}{*}{$\begin{array}{l}\text { Sample } \\
\text { name }\end{array}$} & \multicolumn{4}{|c|}{ Activity concentration, $\mathrm{Bq} / \mathrm{kg}$} \\
\hline & ${ }^{40} \mathrm{~K}$ & ${ }^{137} \mathrm{Cs}$ & ${ }^{226} \mathrm{Ra}$ & ${ }^{232} \mathrm{Th}$ \\
\hline \multicolumn{5}{|c|}{ Critical point } \\
\hline $0-10 \mathrm{~cm}$ & $555.6 \pm 21.7$ & $7 \cdot 6 \pm 3 \cdot 3$ & $33.3 \pm 3.2$ & $19.5 \pm 2.5$ \\
\hline $10-20 \mathrm{~cm}$ & $580.9 \pm 22.7$ & $7 \cdot 3 \pm 3 \cdot 5$ & $35.6 \pm 3.4$ & $21.5 \pm 2.8$ \\
\hline $20-30 \mathrm{~cm}$ & $580.2 \pm 23.2$ & $8.2 \pm 3.8$ & $36.7 \pm 3.5$ & $19.3 \pm 2.9$ \\
\hline $\begin{array}{l}\text { Lower } \\
\text { right } \\
\text { section }\end{array}$ & $598.8 \pm 22.2$ & $7.4 \pm 3.4$ & $33.4 \pm 3.2$ & $26.6 \pm 2.6$ \\
\hline $\begin{array}{c}\text { Lower left } \\
\text { section }\end{array}$ & $572.1 \pm 27.4$ & $8.3 \pm 4.3$ & $35 \cdot 3 \pm 4.2$ & $20.9 \pm 3 \cdot 3$ \\
\hline \multicolumn{5}{|c|}{ Field } \\
\hline Plowed & $679.0 \pm 22.4$ & $5.2 \pm 3.5$ & $37.4 \pm 3.4$ & $29.3 \pm 2.7$ \\
\hline Unplowed & $685.6 \pm 28.1$ & $6.2 \pm 3.8$ & $51.3 \pm 4.2$ & $31.6 \pm 2.9$ \\
\hline \multicolumn{5}{|c|}{ Viliya River } \\
\hline $\begin{array}{c}\text { Above } \\
\text { discharge } \\
\text { point }\end{array}$ & $666.4 \pm 22.0$ & $6.7 \pm 3.5$ & $44 \cdot 6 \pm 3 \cdot 3$ & $37.1 \pm 2.7$ \\
\hline $\begin{array}{c}\text { Below } \\
\text { discharge } \\
\text { point }\end{array}$ & $411.4 \pm 20.1$ & $8.4 \pm 3.4$ & $36.9 \pm 3.1$ & $17.2 \pm 2.6$ \\
\hline $\begin{array}{l}\text { Markuny } \\
\text { village, } \\
\text { downstream } \\
\text { of Polpe }\end{array}$ & $558.9 \pm 19.1$ & $6.1 \pm 3.5$ & $35 \cdot 9 \pm 3.2$ & $27.6 \pm 2.2$ \\
\hline
\end{tabular}

Table 5. Tritium and radiocarbon content of selected vegetation samples

\begin{tabular}{|c|c|c|c|}
\hline Region & Sample & $\begin{array}{c}{ }^{14 C} \\
\text { content, } \\
\text { pMC }\end{array}$ & $\begin{array}{c}\mathrm{H} \\
\text { content, } \\
\mathrm{Bg} / \mathrm{g}\end{array}$ \\
\hline \multirow{5}{*}{$\begin{array}{c}\text { Critical } \\
\text { point }\end{array}$} & Silver birch & $111.5 \pm 4.4$ & $<2.42$ \\
\hline & Stinging nettle & $104.0 \pm 4.3$ & $<2.05$ \\
\hline & Lupinus & $103.8 \pm 3.0$ & $<1.64$ \\
\hline & $\begin{array}{l}\text { Perforate St } \\
\text { John's-wort }\end{array}$ & $103.4 \pm 4.8$ & $<2.10$ \\
\hline & Oak & $102.8 \pm 2.1$ & $<2.15$ \\
\hline \multirow{5}{*}{$\begin{array}{l}\text { Release } \\
\text { point of } \\
\text { NPP }\end{array}$} & Oak & $115.0 \pm 3.0$ & $<2.57$ \\
\hline & Alder & $106.9 \pm 4.5$ & $<2.37$ \\
\hline & Tilia & $112.0 \pm 1.0$ & $<2.53$ \\
\hline & Pine & $98.1 \pm 2.4$ & $<1.90$ \\
\hline & Silver birch & $93.0 \pm 0.7$ & $<2.57$ \\
\hline \multirow{3}{*}{$\begin{array}{l}\text { Viliya River } \\
\text { above and } \\
\text { below the } \\
\text { release } \\
\text { point of } \\
\text { NPP }\end{array}$} & Cladophora & $83.3 \pm 3.6$ & $<1.50$ \\
\hline & Elodea & $82.2 \pm 3.9$ & $<2.90$ \\
\hline & Potamogeton & $78.9 \pm 1.1$ & $<2.94$ \\
\hline \multirow{3}{*}{$\begin{array}{l}\text { Viliya River } \\
\text { at } \\
\text { confluence } \\
\text { of Polpe } \\
\text { River }\end{array}$} & Elodea & $83.4 \pm 2.5$ & $<1.88$ \\
\hline & Cladophora & $75.8 \pm 1.9$ & $<2.73$ \\
\hline & Potamogeton & $74.4 \pm 0.8$ & $<2.89$ \\
\hline
\end{tabular}

The activity concentrations of radiocarbon and tritium content in different samples are presented in Table 5. For terrestrial plants, the ${ }^{14} \mathrm{C}$ content is close to the modern carbon level - $100 \mathrm{pMC}(0.227 \mathrm{~Bq} / \mathrm{g} \mathrm{C})$.
The ${ }^{14} \mathrm{C}$ content in some trees slightly exceeds this level. This may have been caused by different physiological processes in different trees. For aquatic plants, these values may be lower due to the reservoir effect resulting from the presence of a large amount of carbonates in water.

\section{CONCLUSION}

The implementation of a comprehensive field research program in the territory potentially affected by a Belarusian nuclear power plant made it possible to assess the radiation situation in the area during the pre-operational period. In this work, the assessment of the "zero background level" meant determining important parameters characterizing the radiation situation before the start of operations at the Belarusian NPP. These parameters are:

- the photon radiation dose rate $(\mu \mathrm{Sv} / \mathrm{h})$ in the territory adjacent to the nuclear power plant, at the critical point location site and on the banks of the River Viliya;

- the content of gamma-emitting radionuclides (activity concentrations, $\mathrm{Bq} / \mathrm{kg}$ ) in the soil, water and riverbed sediments of the examined sections of the River Viliya;

- the carbon-14 content in the dominant vegetation species at different sites around the Belarusian NPP.

As a result of the pedestrian gamma spectrometric survey at 158 points around the perimeter of the site of the Belarusian NPP (including the "critical" point), the ranges of variation of the measured parameters were established:

- a dose rate from 0.048 to $0.085 \mu \mathrm{Sv} / \mathrm{h}$. A measurement of near-background dose rate levels below $0.1 \mu \mathrm{Svh}$ for the measuring instruments used is described in publications [28-30] in accordance with the requirements of IEC 60846-1 and 61017 [31,32];

- activity concentrations of ${ }^{40} \mathrm{~K}$ (natural radionuclide) - from 530 to $700 \mathrm{~Bq} / \mathrm{kg}$;

- activity concentrations of ${ }^{226} \mathrm{Ra}$ (natural radionuclide) - from 30 to $55 \mathrm{~Bq} / \mathrm{kg}$;

- activity concentrations of ${ }^{232} \mathrm{Th}$ (natural radionuclide) - from 17 to $35 \mathrm{~Bq} / \mathrm{kg}$;

- activity concentrations of ${ }^{137} \mathrm{Cs}$ (technogenic radionuclide) at all measured points are significantly lower than $50.0 \mathrm{~Bq} / \mathrm{kg}$.

- activity concentrations of ${ }^{14} \mathrm{C}$ (natural radionuclide) - from 74.4 to $115.0 \mathrm{pMC}$;

- activity concentrations of ${ }^{3} \mathrm{H}$ (natural radionuclide) - less than lower range limit.

The results of the automotive gamma surveys at 951 points remote from the site of the Belarusian NPP generally coincide with the range of dose rate values (from 0.049 to $0.093 \mu \mathrm{Sv} / \mathrm{h}$ ) from the pedestrian survey results, but differ in the terms of the bimodality of the shape of the distribution function of the repeatability of the results (Fig. 7). The presence of two modes is explained by the difference in the road surfaces (dirt and asphalt) on which the car moved during the survey. 
E. I. Nazarov et al., Radiological assessment of Belarussian NPP, RAD Conf. Proc., vol. 4, 2020, 142-148

The field gamma-spectrometric survey at 33 points of the bank of the Viliya River made it possible to reliably determine the ${ }^{40} \mathrm{~K}$ content (natural radionuclide) at a range from 220 to $701 \mathrm{~Bq} / \mathrm{kg}$, the dose rate being from 0.033 to $0.082 \mu \mathrm{Sv} / \mathrm{h}$. The determination of the activity concentration values of ${ }^{226} \mathrm{Ra}$ and ${ }^{232} \mathrm{Th}$ in the selected areas during the field measurement phase was difficult due to the water content: the values were obtained later as a result of laboratory studies on the selected samples. The gamma-spectrometric survey of the riverbed sediments at 33 points of the Viliya River in three selected areas allowed us to reliably determine the ${ }^{40} \mathrm{~K}$ content (natural radionuclide) at a range from 357 to 745 $\mathrm{Bq} / \mathrm{kg}$. The activity concentrations of ${ }^{137 \mathrm{Cs}}$ (technogenic radionuclide) at all measured points on the riverbank and bed is significantly lower than 50.0 $\mathrm{Bq} / \mathrm{kg}$.

Processing the obtained data during the expedition allowed us to obtain the functions of the distribution of the dose rate and the activity of the radionuclides for all the examined sites. A change in the established ranges of values or a change in the established forms of the functions of dose rate distributions of the obtained values will mean a change in the radioecological situation caused by an external factor.

\section{REFERENCES}

1. Environmental and Source Monitoring for Purposes of Radiation Protection, IAEA Safety Guide № RS-G-1.8., IAEA, Vienna, Austria, 2016. Retrieved from:

https://www.pub.iaea.org/MTCD/Publications/PDF/P ub1216 web.pdf

Retrieved on: 1 March, 2020

2. М. М. Кадацкая, “Требования к организации радиационного мониторинга в зоне наблюдения Белорусской АЭС для целей оценки дозы репрезентативного человека", Здоровье $u$ окружающая среда, т.1, стр. 71 - 73, 2017.

(M. M. Kadackaya, "Requirements for the organization of radiation monitoring in the monitoring area of the Belarusian NPP for the purpose of assessing the dose of a representative person", Health and Environment, vol. 1, pp. 71-73, 2017.)

3. D. Marčiulionienė et al., "137Cs and plutonium isotopes accumulation/retention in bottom sediments and soil in Lithuania: A case study of the activity concentration of anthropogenic radionuclides and their provenance before the start of operation of the Belarusian Nuclear Power Plant (NPP)," J. Environ. Radioact., vol. 178-179, pp. 253-264, 2017.

https://doi.org/10.1016/j.jenvrad.2017.07.024

4. Su. F. Ozmen, "Ecological assessment of Akkuyu nuclear power plant site marine sediments in terms of radionuclide and metal accumulation," Journal of Radioanalytical and Nuclear Chemistry, vol. 325, pp. 133-145, 2020. https://doi.org/10.1007/s10967-020-07201-w

5. R. A. Mikailova, A. V. Panov, D. N. Kurbakov, "The programme and results of the radioecological monitoring of freshwater ecosystems in the vicinity of Rooppur NPP (People's Republic of Bangladesh)," in RAP Conf. Proc., Belgrade, Serbia, 2019, pp. 108-112. https://doi.org/10.37392/RapProc.2019.21.5

6. F.F. Bryukhan, "Atmospheric boundary layer monitoring with the SODAR/RASS system on the
Belarusian NPP site," Atomic Energy, vol. 122, no. 1, pp. 69-74, 2017.

https://doi.org/10.1007/s10512-017-0237-9

7. Е.В. Николаенко, “Анализ основных аспектов организации радиационно-гигиенического мониторинга на этапе строительства Белорусской АЭС," Здоровъе и окружающая среда, т. 1, по. 25, стр. 71-73, 2015.

(E. V. Nikolaenko, "Analysis of the main aspects for organization of the radiation-hygiene monitoring on the construction phase of the Belarusian NPP," Health and Environment, vol. 1, no. 25, pp. 75-78, 2015.)

8. В. Николаенко, В. В. Кляус, "Радиационногигиенический мониторинг для оценки "нулевого" фона вокруг Белорусской АЭС," Здоровъе и окружающая среда, ном. 26, стр. 49-53, 2016.

(E. V. Nikolaenko, V. V. Klyaus, "Radiation hygienic monitoring for assessment of the background level around the Belarusian NPP," Health and Environment, no. 26 , pp. $49-53,2016$.)

9. M. Vasyanovich, A. Ekidin, I. Yarmoshenko, "Radionuclide ratio in TENORM studies," RAD Conf Proc., Niš, Serbia, 2014, pp. 163-166. Retrieved from:

https://www.rad-conference.org/Proceedings$\underline{\text { RAD 2014.pdf }}$

Retrieved on: 1 March, 2020

10. A. A. Ekidin, M. E. Vasyanovich, A. V. Nalivajko, "Gamma-Ray Spectrometry Application for Detection of Anthropogenically Uranium-Polluted Soil," Principles of the Ecology, vol. 6, no. 2, pp. 29-35, 2013. https://doi.org/10.15393/j1.art.2013.2682

11. A. A. Ekidin, M. V. Zhukovskii, M. E. Vasyanovich, "Identification of the main dose-forming radionuclides in NPP emissions," Atomic Energy, vol. 120, pp. 134-137, 2016. https://doi.org/10.1007/s10512-016-0107-x

12. М.Д. Пышкина, "Определение основных дозообразующих нуклидов в выбросах AЭC PWR и ВВЭР," Биосферная совместимость: человек, регион, технологии, № 2(18), стр. 98-107, 2017. (M. D. Pyshkina, "The determination of main doseforming nuclides in NPP PWR and VVER releases," Biospheric Compatibility: Human, Region, Technologies, no. 2(18), pp. 98-107, 2017.)

13. M. Vasyanovich, A. Vasilyev, A.Ekidin, I. Kapustin, A. Kryshev, "Special monitoring results for determination of radionuclide composition of Russian NPP atmospheric releases," Nuclear Engineering and Technology, vol. 51, no. 4, pp. 1176-1179, 2019. https://doi.org/10.1016/j.net.2019.02.010.

14. M. E. Vasyanovich et al., "Determination of radionuclide composition of the Russian NPPs atmospheric releases and dose assessment to population," J. Environ. Radioact., vol. 208-209, article no. 106006, 2019. https://doi.org/10.1016/j.jenvrad.2019.106006

15. A. A. Ekidin et al., "Evaluation of the contribution of technogenic radionuclides to the total activity of NPP emissions on the basis of a simulation model," Atomic energy, vol. 119, pp. 271-274, 2016. https://doi.org/10.1007/s10512-016-0059-1

16. А. В. Васильев, А. А. Екидин, Р. И. Юсупов, А. В. Пудовкин, "Нормативно-методическое обеспечение для подтверждения критериев приемлемости радиоактивных отходов АЭС для захоронения," АНРИ, №4(91), стр. 23-30, 2017. (A. V. Vasil'ev, A. A. Ekidin, R. I. Yusupov, A. V. Pudovkin, "Procedures for confirmation of acceptance criteria for geological disposal of NPPs radioactive waste," ANRI, vol. 4(91) pp. 23-30, 2017.)

17. А. А. Пыркова, А.А. Екидин, К. Л. Антонов, “Поступление инертных радиоактивных газов в 
E. I. Nazarov et al., Radiological assessment of Belarussian NPP, RAD Conf. Proc., vol. 4, 2020, 142-148

атмосферу при нормальной эксплуатации АЭС,” В сборнике: Физика. Технологии. Инновации, УрФУ, Екатеринбург, Россия, 2019, стр. 279-287.

(A. A. Pyrkova, A. A. Ekidin, K. L. Antonov, "Discharge of radioactive noble gases to the atmosphere during the normal NPP operation," In proceedings: Physics. Technologies. Innovation, UrFU, Ekaterinburg, Russia, 2019, pp. 279-287.)

Retrieved from:

http://hdl.handle.net/10995/78826 Retrieved on: March 1, 2020

18. A. A. Ekidin, K. L. Antonov, M. E. Vasyanovich, I. A. Kapustin, I. Yu. Filatov, "Radioiodine release into the atmosphere during normal operation of nuclear power plants," Radiochemistry, vol. 61, pp. 352-364, 2019. https://doi.org/10.1134/S1066362219030111

19. Е.Л. Мурашова, А. С. Антушевский, М. Е. Васянович, А. А. Екидин, "Метод жидкой сцинтилляции для определения объемной активности стронция-9о в источниках выброса," АНРИ, №1(96), стр. 17-26, 2019.

(E. L. Murashova, A. S. Antushevskij, M. E. Vasyanovich, A. A. Ekidin, "Liquid scintillation method for determination of strontium-90 concentration in airborne discharge," ANRI, no. 1 (96), pp. 17-26, 2019.)

20. Д. Д. Десятов, А. А. Екидин, "Оценка поступления трития в окружающую среду от выбросов АЭС,” Биосферная совместимость: человек, регион, технологии, № 1(21), стр. 88-96, 2018.

(D. D. Desyatov, A. A. Ekidin, "Evaluation of tritium's entry into the environment from nuclear power plants' emissions," Biospheric Compatibility: Human, Region, Technologies, vol. 1 (21), pp. 88-96, 2018.)

Retrieved from:

https://www.elibrary.ru/download/elibrary 34959688 45026833.pdf

Retrieved on: March 1, 2020

21. Е. И. Назаров, А. А. Екидин, А. В. Васильев, “Оценка поступления углерода-14 в атмосферу, обусловленного выбросами АЭС," Известия высших учебных заведений. Физика, Т. 61, № 12-2 (732), стр. 67-73, 2018.

(Nazarov E.I., Ekidin A.A., Vasilyev A.V., "Assessment of the atmospheric carbon-14 caused by NPP emissions." Proceedings of Higher Educational Institutions. Physics, vol. 61, no. 12-2 (732), pp. 67-73, 2018.)

22. A. I. Kryshev et al., "Population irradiation dose assessment for ${ }^{14} \mathrm{C}$ emissions from NPP with RBMK1000 and EGP-2 reactors," Atomic Energy, vol. 128, pp. 53-59, 2020. https://doi.org/10.1007/s10512-020-00650-2

23. X. Hou, "Tritium and $14 \mathrm{C}$ in the Environment and Nuclear Facilities: Sources and Analytical Methods," Journal of Nuclear Fuel Cycle and Waste Technology, vol. 16, no. 1, pp. 11-39, 2018. https://doi.org/10.7733/jnfcwt.2018.16.1.11

24. A. I. Lysikov et al., "Novel Simplified AbsorptionCatalytic Method of Sample Preparation for AMS analysis designed at the Laboratory of Radiocarbon Methods of Analysis (LRMA) in Novosibirsk Akademgorodok," International Journal of Massspectrometry, vol. 433, pp. 11-18, 2018. https://doi.org/10.1016/j.ijms.2018.08.003

25. V. V. Parkhomchuk, S. A. Rastigeev, "Accelerator mass spectrometer of the center for collective use of the Siberian Branch of the Russian Academy of Sciences," Journal of Surface Investigation, vol. 5(6), pp. 1068-1072, 2011. https://doi.org/10.1134/S1027451011110140

26. А.О. Грубич, “Загрязнение почвы атмосферными выпадениями. Статистические свойства" Минск: ИВЦ Минфина, 230 с., 2017.

(A. O. Grubich, "Soil contamination by atmospheric fallout. Statistical properties," 230 pages, 2017.)

27. А. Г. Подоляк, Г. В. Седукова, С. А. Исаченко, "Мониторинг содержания радионуклидов в компонентах агроэкосистем в зоне воздействия строящейся Белорусской АЭС,” В сборнике: Экологическая и радиационная безопасность объектов атомной энергетики. Материалы IV научно-практической конференции, 2017 стр. 56-60.

(A. G. Podolyak, G. V. Sedukova, S. A. Isachenko, "Monitoring of radionuclide concentrations in agroecosystems within the impact area of underconstruction Belarusian NPP," Proceedings from Environmental and Radiation Safety of Nuclear Power Facilities, 2017, pp. 56-60.)

28. Р. В Лукашевич, В. Д. Гузов, В. А. Кожемякин, А. В. Оборин, "Сцинтилляционные блокикомпараторы для измерений мощности кермы в

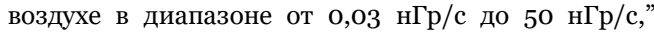
Метрология и приборостроение, №1, стр. 33-37. (R. V Lukashevich, V. D. Guzov, V. A. Kozhemyakin, A. V. Oborin, "Scintillational blocks-comparators to measure kerma power in air withing the range from $0.03 \mathrm{nGr} / \mathrm{s}$ to $50 \mathrm{nGr} / \mathrm{s}$," Metrology and Instrumentation, vol. 1, pp. 33-37, 2017.)

29. R. Lukashevich, Yu. Verhusha, V. Guzov, V. Kozemyakin, "Application scintillation comparators for calibration low intense gamma radiation fields by dose rate in the range of $0.03-0.1 \mu \mathrm{Sv} / \mathrm{h}$," Engineering of Scintillation Materials and Radiation Technologies, pp. 221-235, 2019. https://doi.org/10.1007/978-3-030-21970-3_16

3о. Р. В Лукашевич, В.Д. Гузов, В.А. Кожемякин, “Дозиметрия полей гамма-излучения околофонового уровня с использованием высокочувствительного сцинтилляционного блокакомпаратора," АНРИ, №3(98), стр. 29-41, 2019. (R. V Lukashevich, V. D. Guzov, V. A. Kozhemyakin, "Dosimetry of photon radiation fields of nearbackground level using highly sensitive scintillation comparator," ANRI, no. 3(98), pp. 29-41, 2019.)

31. Radiation protection instrumentation Transportable, mobile or installed equipment to measure photon radiation for environmental monitoring, IEC 61017:2016, Geneva, Intern. Electrotechnical Commiss., 86 pages, 2016.

32. Radiation protection instrumentation - Ambient and/or directional dose equivalent (rate) meters and/ or monitors for beta, $X$ and gamma radiation. Part 1 : Portable workplace and environmental meters and monitors: IEC 60846-1:2009, Geneva: Intern. Electrotechnical Commiss., 116 pages, 2019. 